YEARBOOK

of ANTITRUST

and REGULATORY

STUDIES

www.yars.wz.uw.edu.pl
Peer-reviewed scientific periodical, focusing on legal and economic issues of antitrust and regulation. Creative Commons Attribution-No Derivative Works 3.0 Poland License.

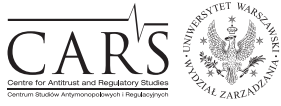

Centre for Antitrust and Regulatory Studies, University of Warsaw, Faculty of Management www.cars.wZ.uw.edu.pl

\title{
The Concept of Unity in the Competition Law System
}

\author{
by
}

\author{
Kamil Dobosz
}

\section{CONTENTS}

I. Introduction

1. EU competition law

2. National competition law sensu stricto

3. National competition law sensu largo

4. Competition law sensu largissimo

II. Competition legal order in disorder

III. The concept of unity

1. Attempting to define unity

2. Unity as a tool to materialise the single market from the competition law perspective

3. Struggles to attain unity from the multi-faceted perspective

4. Striving for unity in light of a 'sponge hallmark'

IV. Challenges of EU competition law enforcement

V. Practical usefulness in light of doubts around public procurement

VI. Unity through the lens of the Polish legal environment

VII. Unity and uniformity

VIII. Unity and effectiveness

IX. Desiderata

1. Roles to cast by the CJEU

2. Towards bold EU harmonisation of all competition law pillars

3. Presumption - interpretation in line with EU competition law

X. Conclusions

* Ph.D. in Law, attorney at law, affiliated to Uniwersytet Pedagogiczny im. Komisji Edukacji Narodowej w Krakowie; e-mail: kd1906@op.pl. Article received: 1 June 2018; accepted: 28 September 2018. 


\section{Abstract}

The paper presents four pillars of competition law that can be recognised in the European Union and Member States, namely EU competition law, national competition law sensu stricto, national competition law sensu largo and competition rules sensu largissimo. In order to demonstrate that this multi-faceted and complex system is able to work in an orderly manner, it is considered in relation to various concepts, particularly unity, uniformity and effectiveness. Nevertheless, the concept of unity serves as a focal point for the observations. The perspective of the EU single market plays a part also, enhancing the call for unity. With regard to discussed threats for unity, possible solutions are proposed in the final part of the article.

\section{Résumé}

Larticle traite de quatre piliers du droit de la concurrence qui existe dans l'Union européenne et dans les États membres, à savoir le droit de la concurrence de l'UE, le droit de la concurrence national au sens strict, le droit de la concurrence national au sens large et les règles de la concurrence au sens large. Afin de démontrer que ce système multiforme et complexe est capable de fonctionner de manière ordonnée, il est considéré en relation avec divers concepts, notamment l'unité, l'uniformité et l'efficacité. Néanmoins, le concept d'unité sert de point focal pour les observations. La perspective du marché unique de l'UE joue également un rôle, renforçant l'appel à l'unité. Dans la dernière partie de l'article, des solutions possibles aux menaces discutées pour l'unité sont proposées.

Key words: Unity; EU competition law; principle of effectiveness; uniformity; national competition rules sensu stricto; national competition rules sensu largo; competition rules sensu largissimo.

JEL: K21

\section{Introduction}

How broad is the scope of competition law in the European Union and its Member States? Does the complex nature of this legal landscape entail some difficulties? Are there any practical ramifications stemming from this comprehensive system? What instruments could be utilised to ensure it works properly? The paper attempts to answer these questions. To this end, the possible pillars of competition law are classified first. The irreconcilable interests each of the pillars aims for are noted as well. Accentuated references to public procurement law and their intersection points complete/complement 
this pattern. Besides, the Polish perspective serves as an epitome showing how complicated the domestic competition legal order can be. The paper covers also a number of cases as examples which demonstrate how, in practice, Member States may fail to apply relevant competition rules or to inter-mix them. Moreover, the paper covers also other incongruences in relation to the paradigms of competition law. The concept of unity, defined beforehand, is proposed to tackle all indicated pitfalls of competition law. Moreover, the concepts of uniformity and effectiveness as well as the EU single market perspective reinforce efforts to guarantee that the competition law pillars are not in disorder. To accomplish unity, several desiderata are described in the final part of the paper.

\section{EU competition law}

Obviously, EU competition law has to be discussed firstly. It consists of an array of legal acts, such as Regulation 1/2003', Directive 2014/104/EU ${ }^{2}$ and related relevant domestic acts. ${ }^{3}$ As regards the latter ones, they pertain to those Member States' acts that are destined to facilitate the application of EU (substantive) norms in proceedings before domestic authorities and courts. ${ }^{4}$ To differentiate them, a useful hint is that they may be subject of an assessment of the Court of Justice in a relatively unfettered way, particularly through the lens of principle of effectiveness. Therefore they simply serve to ensure, from the technical side, that EU provisions can be applied effectively. In further considerations, the EU law perspective may be overwhelming due to its unquestionable position, the principle of supremacy and the impact it exerts at, actually, all competition regimes across Europe.

1 Council Regulation (EC) No 1/2003 of 16 December 2002 on the implementation of the rules on competition laid down in Articles 81 and 82 of the Treaty, OJ L 1, 04.01.2003, p. 1-25.

2 Directive 2014/104/EU of the European Parliament and of the Council of 26 November 2014 on certain rules governing actions for damages under national law for infringements of the competition law provisions of the Member States and of the European Union, OJ L 349, 05.12.2014, p. 1-19.

3 Not to mention the case-law.

${ }^{4}$ Since EU competition law covers virtually no procedural norms for proceedings before national courts and authorities. 


\section{National competition law sensu stricto}

The second paradigm is associated with national competition law governing rules applicable to undertakings ${ }^{5}$ embroiled in anticompetitive conducts, either of minor relevance, as they are not the subject of interest from the EU competition law perspective, or which are covered by the application of domestic competition law in parallel with EU competition law. ${ }^{6}$ To keep it as simple as possible, these domestic competition rules are equivalent to Articles 101 and 102 TFUE$^{7}$. For this reason, they can be applied in a parallel manner with the provisions of the Treaty - otherwise they would constitute a different legal basis. Let's call them the national competition rules sensu stricto.

In terms of application of substantive competition law, it is the metha-norm of the inter-state trade criterion that delineates situations when solely national competition law sensu stricto can be applied, and when EU competition law can be enforced as well. Simplifying, they both can collectively be called 'antitrust law'. Likewise, they both belong to the core of - what is commonly referred to as - competition law, in contrast to another package of rules described directly below.

\section{National competition law sensu largo}

Other national rules related broadly to competition law, but comprising the third pillar in this regard, have been named here 'national competition law sensu largo'. More concrete examples will be discovered below, in this section a brief general picture ought to be presented.

National competition rules sensu largo serve when the prerequisites to apply antitrust law are not met, often due to its severity. ${ }^{8}$ Alternatively, they are chosen by authorities in replacement of EU competition law or national competition rules sensu stricto in order to potentially circumvent them. This may happen if specific circumstances cannot be assessed in one fashion only.

5 Due to the comprehensive nature of the paper and variety of legal acts covered therein, I will be using interchangeably the following notions 'undertaking', 'company', 'firm' and 'entrepreneur', although it should be remembered that they may not fit a legal micro-system of the concrete legal acts studied individually.

6 Providing that a concept of single barrier is not established in a given jurisdiction: Komninos, 2008, p. 66-67.

7 Treaty on the Functioning of the European Union. Consolidated version [2010] OJ C 83/47.

${ }^{8}$ For instance, the prerequisites of abuse of dominance are severe contrary to national rules on combating unfair competition. 
The national authority decides then to avoid the antitrust regime in favour of - for instance - a less complicated evidence presentation procedure. Even if the criterion of inter-state trade is satisfied, an assessment that the case is not of antitrust nature releases authorities from many procedural and technical obstacles. Thus these legal rules can work out where antitrust law fails. Not to mention, if non-antitrust legal basis is chosen by the NCAs, they are not obliged to coordinate their operation with the European Competition Network (more Cengiz, 2010). It may fasten and simplify the proceedings what for the NCAs may be crucial.

\section{Competition law sensu largissimo}

Indisputably, antitrust law is commonly considered a separate branch of law. Some doubts regarding its specific institutions, whether they belong to penal or administrative law, are not capable of blurring this position. Moreover, many facets originating in antitrust law have spread to other fields of law. In terms of intersection points, there can be serious uncertainty because theoretically two sets of rules might be employed, either competition law or the other relevant field of law. From the angle of competition law, of utmost importance is the choice of its own set of rules, legal institutions, definitions, case-law etc. The reasons are obvious - to maintain an overall uniform and effective application of competition law. While this paper demonstrates how problematic such deviations from antitrust law may be, it is a call for unity that is needed to prevent further erosion of antitrust issues whenever they are dealt with in cases of other fields of law. Anyway, whatever field of law is examined, be it European or domestic, it should be treated with the concept of unity, providing that that field (inter)relates to competition law. Thus, collectively, those fields of law can refer to as competition law sensu largissimo.

\section{Competition legal order in disorder}

Undertakings bear the burden of compliance with EU competition rules, national competition rules sensu stricto, national competition rules sensu largo and competition law sensu largissimo, since they all together comprise the competition law system in the EU and Member States. Undoubtedly, the issues outlined above feature a multi-layer complexity as, in addition, they may appear as cases exclusively at the EU level, exclusively in one Member State but also in various Member States. The probability that the mechanisms 
of such a complex system fail is extremely high; albeit it does not amount yet to the certainty that the discussed legal order is in disorder, but it is a justifiable conjecture. Besides, the notion of 'order' is not entirely clear either.

To proceed in an orderly manner, this paper proposes at once to utilise the concept of unity because the terms 'order' and 'unity' have more in common, as the definition below suggests. Therefore, there are the following steps to take: firstly, the concept of unity will be discussed in genere; secondly, various contexts motivating a call for unity will be demonstrated; and thirdly, from this perspective, the Polish legal landscape will be described as a concrete Member State example. As regards the more abstract part of unity, the concept of unity will be additionally confronted with two adjacent terms, namely uniformity and effectiveness. Before the conclusions are drawn, several desiderata aimed at the accomplishment of unity will be raised. It should be also mentioned that, due to the complexity of the researched area, the relationship between public procurement and competition law will serve as a representative example demonstrating to what extent various discrepancies exist in one legal space, although other relevant fields of law will be accordingly signalled as well.

\section{The concept of unity}

\section{Attempting to define unity}

M. Avbelj proposes to define unity 'as a legal order which is complete or entire in itself and, as such, allows only for a limited degree of diversity' (Avbelj, 2006). Seemingly, unity still leaves room for some degree of diversity. Its scope should be optimally narrow so as for the distinctions not to eradicate their functioning in one common legal space. Indeed, unity demands that all pertinent constituents and prongs of a legal system - in this case, competition law - are internally compatible. By the same token, lacunae in law are in clash with unity since the criterion of entirety is not satisfied. If some relevant subfields of law are located beyond the law at stake, it cannot be complete either.

Importantly for this definition, a crucial role is also played by the widely perceived competition law, referring to elements relatively remote from the core of antitrust as explained above. Even indirect connections may be seminal heeding a premise of entirety of a legal system, as M. Avbelj defines it.

Striving to seek a correct definition of the term 'unity' directly within the researched field of law, the undertaken approach should outreach the default association of EU competition law limited only to Articles 101 and 102 TFUE. Its breadth covers the norms of the Treaty as well as related secondary and 
soft sources of law and yet the European Union competition system consists also of other provisions. Questions of compatibility and integrity of private and public enforcement (see more inter alia in Jurkowska-Gomułka, 2013, Hüschelrath, Schweitzer, 2014, Komninos, 2014 and Wils, 2017) do not constitute the entire picture of the competition law landscape either, although the expansion of the private paradigm triggered by the new directive ${ }^{9}$ brings forth opportunities as well as jeopardises unity altogether. Taking it all into account, the aforementioned pillars had to have such a comprehensive scope.

The concept of unity cannot be considered a synonym for 'compatibility' or 'integrity' 10 either, since they are aimed at the internal coherence and cooperation between the relevant system's elements. Unity, on the other hand covers - aside these factors - also a top-down design in the lawmaking process in order to pursue intended goals. Pursuing EU economic law not only consists of accommodating an array of legal acts, but making them a legal and policy tool to achieve goals conceived beforehand. Similarly 'pluralism' cannot be recognised as an opposite notion to 'unity'. ${ }^{11}$ It is quite the contrary - the competition law system is full of various legal institutions, as palpable in the context of its four dimensions. Thus it is that difficult to find a common denominator.

\section{Unity as a tool to materialise the single market from the competition law perspective}

The concept of unity can be easily justified on the grounds of a salient EU goal, which is the promotion of European (market) integration by means of law (see e.g. Cseres, 2005, p. 81-82). As Member States are obliged to attain it as well, unity shall apply to all dimensions of competition law. Indeed, if the pertinent legal acts comprising the competition law system were mutually 'coordinated', it would simply bridge the gaps in the cross-border prism of the European Union. The same denominator for the legal provisions binding in Member States would literally produce a great integration effect.

9 Directive 2014/104/EU of the European Parliament and of the Council of 26 November 2014 on certain rules governing actions for damages under national law for infringements of the competition law provisions of the Member States and of the European Union, OJ L 349, 05.12.2014, p. 1-19.

10 Integrated (and sustainable) model of competition law enforcement in terms of its private and public paradigm was contemplated in Jurkowska-Gomułka, 2013, passim.

${ }^{11}$ Slightly different conclusion can be drawn in other fields of law - see e.g. A. Casanovas, 2001. 
A peculiarity of EU law, particularly as it interacts with national sources of law, justifies a simplified approach in defining unity in comparison to other fields of law (see a thorough study devoted to unity in law generally: Prost, 2012). It should be remembered after all that European integration is a mainstay of the EU law system. When it comes to the EU competition law system, the economic emanation thereof is the level-playing-field for entrepreneurs as a consequence of the idea of a borderless Europe. This course has been recently confirmed in the proposal ${ }^{12}$ for Directive ECN+" (Materna, 2018 and Sinclair, 2017), alternatively the Effectiveness Directive (Dobosz, Scheibe, 2017). That initiative can be hence identified as a signal that in terms of B2B formula the European Commission will engage in attempts to attain the single market ${ }^{13}$ in a wider scope than ever before. ${ }^{14}$ Thus it is necessary to ensure that both the EU and national rules are compatible to an extent that they do not create uneven conditions for business. ${ }^{15}$ Otherwise no unity in law will be reached whatsoever. As a matter of fact, the shortage of methods employed to enhance and improve B2B in the EU may be perplexing, taking into account how EU antitrust law is insufficient to meet the expectations to attain the single market. It should be recalled that fostering the single market was entrenched in the EU competition law system for years. ${ }^{16}$ Furthermore, the single market features the malleable nature (Weatherill, 2017, p. 2).

Unfortunately, EU antitrust law captures nowadays merely a fragment of the sequence of possible behaviours of undertakings. Just to illustrate - a dominant position cannot be reached easily, owing to the requirement of holding market power, a fact that results in a narrower scope of rules concerning abuse of dominance. The same story regards multilateral anticompetitive practices, as they still have to be qualified as sufficiently appreciable in order to fulfil the premise of an effect on EU trade. Thus the remainder is left to national legislations, a fact that may consequently generate discrepancies across Member States.

The debate on the single market reform is lively (see Koutrakos, Snell, Eds., 2017), but mostly focused on the four freedoms - against that backdrop,

12 Proposal for a Directive to empower the competition authorities of the Member States to be more effective enforcers and to ensure the proper functioning of the internal market, $\operatorname{COM}(2017) 142$ final.

13 Simplifying, I use internal market and single market exchangeably.

14 Needless to say, more attention could have been apparently noticed as regards consumers in lieu of companies - see e.g. http://europa.eu/rapid/press-release_IP-18-3041_en.htm (access 23-05-2018).

15 Compare judgement of the Court of 14.09.2010, C-550/07 P Akzo Nobel Chemicals Ltd, Akcros Chemicals Ltd v European Commission, ECLI:EU:C:2010:512, para. 115.

16 For instance see judgement of the Court of 01.06.1999, Case C-126/97, Eco Swiss China Time Ltd v Benetton International NV, EU:C:1999:269, para 36. 
this article forays that area along with broadly understood competition law. Similarly, a contention that EU antitrust law is focused on most important infringements can no longer be defended, because the concept of the single market rudimentarily contradicts a cross-border perspective in the EU (compare: K. Dobosz, 2018a). Besides, there is the European Union's interest in ensuring compliance with the rules on competition and the preservation of the unity of the single market, invoking an opinion of Advocate General Cruz Villalon ${ }^{17}$ who, in turn, referred to EU case-law ${ }^{18}$. It has to be understood cumulatively, otherwise it would be pointless.

\section{Struggles to attain unity from the multi-faceted perspective}

Pursuing a goal of unity requires multiple efforts dedicated to EU competition law, the national competition law sensu stricto, the national competition law sensu largo and the competition law sensu largissimo. However, adjustments to other EU rules are necessary as well. Thus it should not only be expected to reconcile - for instance - how efficiencies are understood in light of Articles 101 and 102 TFEU in comparison to the control of concentrations ${ }^{19}$ but - what is far more challenging - to do so whilst the EU public procurement norms are at stake, they are based in as close a manner on the EU competition law as is feasible. Conciliating EU antitrust law with other EU regulatory regimes is another staple of incremental demand for unity. ${ }^{20}$ In this respect, reaching unity involves legislative initiatives as well.

Being limited merely to solving ad hoc problems - particularly in the course of the application of the law - does not address the unity issue in the long term. The current stage of EU law development requires, during the lawmaking process, a wide inclusion of interrelations emerging on adjacent fields, such as public procurement and antitrust. All the more, this applies to the domestic legal domain. The competition law system, for its own good, deserves much more than just a casuistic approach. It is unquestionable that

17 Opinion of Advocate General Cruz Villalón delivered on 30 April 2013, Case C-518/11, UPC Nederland BVv emeente Hilversum, ECLI:EU:C:2013:278, para. 73.

18 Mainly: judgement of the Court of 21.09.1999, Case C-67/96, Albany International BV v Stichting Bedrijfspensioenfonds Textielindustrie, ECLI:EU:C:1999:430, para. 103 and judgment of the Court of 20.04.2010, Case C-265/08, Federutility and Others v Autorità per l'energia elettrica e il gas, ECLI:EU:C:2010:205, para. 29.

19 See Tosza, 2009 as well as OECD document: The Role of Efficiency Claims in Antitrust Proceedings, DAF/COMP(2012)23, available at http://www.oecd.org/competition/ EfficiencyClaims2012.pdf (15-05-2018).

${ }^{20}$ Judgement of the Court of 23.01.2018, Case C-179/16, F. Hoffmann-La Roche Ltd and Others v Autorità Garante della Concorrenza e del Mercato (AGCM), EU:C:2018:25. 
the interpretation of EU competition law opens a range of options, that help attain unity, but the principle of certainty of law militates against such - too loose - solutions, especially when it could be quite easily handled by the lawmaking process.

Efforts to ensure that EU antitrust law remains seamlessly consistent with the EU, national and international intellectual property law constitutes another piece in the competition law puzzle (the impact of IP law on competition is amply elucidated in D. Miąsik, 2012, p. 106-143 and Raju, 2015, passim). A specific sectorial regulatory framework can be perceived in the same vein, albeit in addition it is generally governed by ex ante rules (just like the telecommunications sector-Stolarski, 2015, p. 30 et seq. and generally Hou, 2015). The Fintech revolution may raise antitrust concerns as well (see Stolarski, 2018). In so far as even consumer law, or other national laws of competition law sensu largo, feature potential confluence with EU competition law or national competition law sensu stricto, this issue has to be also addressed - otherwise the abovementioned casuistic approach will not be defeated. Moreover, national laws classified as competition rules sensu largo may play a major role in situations where EU competition law apparently fails. Hence it should not be abandoned. For example, possibly anticompetitive non-controlling minority shareholdings (Gassler, 2018) are largely overlooked by the EU competition lawmaker and its enforcers, whereas domestic laws are well placed to overcome such problems. ${ }^{21}$ In fact, domestic laws may fit in a supplementary way to EU competition acts comprising additional and complementary tools in building the competition law system. The potential blemish is a lack of unity. This lesson has to be learned from relatively theoretical considerations, like from this paper, before failures will appear in practice.

\section{Striving for unity in light of a 'sponge hallmark'}

EU competition law undoubtedly covers a diversity of issues. The goals it protects, and the accompanying debate in this regard, seem to become a never-ending story. Nonetheless, as explained above, there are some firm prerequisites establishing whether the case is of EU nature or not. In an ideal world, it is a premise of interstate trade. On the other hand, awareness of the mere fact that each competition regime is susceptible to capture a vast number of aspects - a 'sponge hallmark' (Ezrachi 2017) - is not helping in

21 Similar conclusion may be drawn to vexatious litigation which may be embraced by such national acts 'softer' than EU competition acts. As regards controversies aroused by vexatious litigation see Lianos, Regibeau, 2017 and Dudzik, 2013. 
striving for unity with regard to the competition law system in the EU and its Member States. None of two competition regimes are alike, but due to their peculiarities, they may differ on many surfaces or in relation to many aspects. This appears to be the issue in the context of EU competition rules and national competition rules sensu stricto. If you add national competition law sensu largo and competition law sensu largissimo, it cannot be conceived what consequences such a concoction will have.

\section{Challenges of EU competition law enforcement}

Broadly speaking, unity of competition law in the EU and its Member States includes also national legislation in so far as it overlaps with Articles 101 and 102 TFEU. Member States are authorised to maintain their own law according to Article 3 ( 2 and 3) Regulation 1/2003. It occurs, however, that Member States dare to go for legislation which is somewhat dubiously aligned with the EU antitrust regime. ${ }^{22}$ For instance, the so-called 'Macron's Law' regulates MFN clauses much more restrictively than can be inferred from the case-law based on EU competition law, which does not leave any room for opposite adjudications from the EU side. A practical scope to justify national provisions on the grounds of Article 3 (2/3) Regulation 1/2003 is nebulous (see my further considerations: Dobosz, 2018b and Dobosz, 2018a).

Similarly, one of the practical cases that triggers doubts concerns the Bundeskartellamt's approach towards Facebook, where the German authority seemingly steered away from EU competition rules in favour of domestic norms (more Massolo, 2018). It should be borne in mind that considering the application of Article 102 TFEU, the inter-state criterion would be incredibly likely satisfied. Regardless of the controversies this approach brought about, it illustrates perfectly that, in fact, it is impossible to state categorically that a disputed behaviour can be assessed through the lens of EU or national competition law, be it sensu stricto or sensu largo.

As proven in literature (Botta, Svetlicinii, Bernatt, 2015 and Cseres, 2017, p. 184-185), some authorities did not go for the antitrust norms envisaged in the Treaties, a situation also called 'under-enforcement' of EU competition law (Malinauskaite, 2016, p. 28). Rather than EU rules, national equivalents were applied. This paper puts forward a similar problem also when a NCA refuses to choose Article 101 or 102 TFUE (and their national equivalents) with respect of a given misconduct. Instead, its decision is based on domestic competition

${ }^{22}$ See https://www.legifrance.gouv.fr/affichTexte.do?cidTexte=JORFTEXT000030978561\& categorieLien $=$ id $(22.10 .2018)$. 
rules sensu largo, which became 'false substitutes' to EU competition law as well as national competition law sensu stricto. In other words, the burden of the application of the law is shifted from quantitative assessment, whether a case at issue is of EU nature, to a qualitative assessment, that the case belongs solely to the domestic domain, a result of a subsumption process. To prevent such failures, relevant legal acts have to be mutually coordinated so as to reach unity.

\section{Practical usefulness in light of doubts around public procurement}

EU public procurement law remains one of the realms most affected by competition aspects, ${ }^{23}$ its particular approach to competition produces dissociating effects from the EU antitrust core. Employing antitrust terminology in the public procurement regime without any coordination hinders the accomplishment of unity's goal (compare Sánchez Graells, 2011, p. 11 et seq. and Priess, 2014). What's even worse, acute problems with Article 57(4d) Directive 2014/24/EU ${ }^{24}$ represent striking designata for this contention (see Dobosz, 2017). Entrepreneurs fined for an antitrust delict (by competition authorities) may be excluded from the participation in public tenders in that Member State, but not in other Member States, in spite of having been sentenced for an anticompetitive behaviour in the common market (ibidem, p. 76-84). Besides, it is unknown whether the criterion of inter-state trade plays a role in terms of a possible exclusion of undertakings, although national competition rules may significantly deviate from EU competition law whilst being applied in a purely domestic case.

Nevertheless no one attempted to use this legal possibility so as to eliminate a competitor who committed an anticompetitive delict elsewhere. Hence, unfortunately, no case-law can be presented in this regard. Thus, much room remains for a further, rather theoretical, discussion. Moreover, taking into account the creativeness of legal counsels, such issues will pop up in practice sooner rather than later. Academia (see Sánchez-Graells, 2019, p. 4-8) did not come up with an unequivocal stance, especially as regards another similar premise of exclusion (Article 57(4c) of Directive 2014/24/EU). This raises a question whether competition law in the EU and Member States is indeed

23 The common story of procurement law and competition law since the Rome Treaty is sufficiently described in Dzierżanowski, 2012, p. 19 et seq.

${ }^{24}$ Directive 2014/24/EU of the European Parliament and of the Council of 26 February 2014 on public procurement and repealing Directive 2004/18/EC, OJ L 94, 28.03.2014, p. 65-242. 
doomed to be disordered whenever competition aspects more or less remote from the core of antitrust are at stake?

\section{Unity through the lens of the Polish legal environment}

When it comes to national jurisdictions, it is possible to find such legal acts that may interfere with each other shaping the competition law environment. Granted that there are serious inter-links between EU antitrust law and domestic legal acts, as well as other sources of law, in each country, and it is an extraordinary challenge to capture them at all. Goals of competition law may even differ depending on the country in question (Miąsik, 2012, p. 44 et seq.).

First, limiting itself only to domestic legal acts that are binding in Poland, the following laws should be listed:

- Act on competition and consumer protection (hereinafter; ACCP); ${ }^{25}$

- Act on combating unfair competition; ${ }^{26}$

- Act on combating the unfair use of superior bargaining power in the trade in agricultural and food products (hereinafter; Act on unfair use); ${ }^{27}$

- Act on claims for damages arising from competition law infringement; ${ }^{28}$

The catalogue above contains solely the most conspicuous acts between which the essential interaction is present. Moreover, it comprises merely domestic acts, whereas there are also stricte acts of the European Union that jointly affect the activities of undertakings in Poland. Hence as regards EU acts, these are as follows:

- Regulation $1 / 2003$;

- Directive 2014/104/EU;

- other, including a 'Directive ECN+' providing that it will be eventually adopted and subsequently implemented.

Virtually all acts may be intertwined in terms of a few criterions. First, they restrain business activities from the angle of the whole competition law package of acts. Hence companies have to comply with an array of legal regulations, thwarting a breach of any of them. Normally, the same legal team specialises

25 Ustawa z dnia 16 lutego 2007 r. o ochronie konkurencji i konsumentów, tj. Dz.U. 2018 poz. 798 .

26 Ustawa z dnia 16 kwietnia 2003 r. o zwalczaniu nieuczciwej konkurencji, tj. Dz.U. 2017 poz. 419.

27 Ustawa z dnia 15 grudnia 2016 r. o przeciwdziałaniu nieuczciwemu wykorzystaniu przewagi kontraktowej w obrocie produktami rolnymi i spożywczymi, Dz.U. 2017 poz. 67 ze zm.

28 Ustawa z dnia 21 kwietnia 2017 r. o roszczeniach o naprawienie szkody wyrządzonej przez naruszenie prawa konkurencji, Dz.U. 2017, poz. 1132. 
in this element of the legal space and provides services for the clients to bring about compliance. In addition, those norms directly or indirectly protect competitors, customers and small (and alternatively medium) companies.

Second, they may stipulate that one business conduct could be potentially a subject of a compliance process encompassing several acts (due to a confluence). It may apply to deeds which can be hypothetically outlawed as an abuse of dominance (Article 9 ACCP, Article 102 TFEU), misconduct in the food supply market ${ }^{29}$, and a delict in the sense of the Act on combating unfair competition. Basically, a delineation between them may not be always feasible, as it certainly regards the latter in relation to other legal acts (Handig, 2006, p. 45-47). Certain factual situations recognised by one of the aforementioned acts may have key impact on the regime of another act. An illegal collusion between entrepreneurs, which was detected and sanctioned by a competition agency, both by virtue of EU and Polish regulations, may be subsequently brought before the civil courts in damages proceedings as well as treated as a premise that precludes the companies' participation in public procurement tenders. Not to mention that in terms of bid rigging, penal proceedings may be independently initiated against natural persons. The obviously outlined track may not be necessarily the same and may be prone to varying factors. In any event, the aforementioned legal possibilities in how to deal with certain behaviours clearly indicate a practical scope of the problems discussed in this paper.

Another, half serious, issue is that when one says 'competition law' in Polish ('prawo konkurencji'), no one really knows what is on the speaker's mind if there was no prior context mentioned. The reason is that it may pertain to public antimonopoly ${ }^{30}$ law, unfair competition law or even consumer law and the private pillar of antimonopoly law (Bernatt, 2014). Due to the official name for the Polish competition agency, that is, Urzad Ochrony Konkurencji i Konsumentów (UOKiK - Polish Competition and Consumers Protection Office), it has been coined that 'competition protection law' is a synonym to public antimonopoly law. Even basic literature, namely M. Kępiński (Ed. 2014). System Prawa Prywatnego. Tom 15. Prawo konkurencji, Warszawa: C.H. Beck, was categorized in a book series dedicated to private law, despite containing chapters both on public and private law; moreover, 'competition law' was associated with several sub-fields of law. At any rate, stating 'competition law' in Polish has to be complemented by accompanying accurate information.

29 Proposal for a Directive on unfair trading practices in business-to-business relationships in the food supply chain (COM/2018/0173 final - 2018/082 (COD)), mentioned above, providing adoption by EU institution, will change it.

${ }^{30}$ In Polish the word 'antimonopoly' is much more preferred than 'antitrust'. 
Furthermore, it should be borne in mind that some of the undertakings' behaviours above are examined in administrative proceedings before the President of UOKiK and subsequently before the courts (if an appeal has been submitted). As regards another category of cases, concerning private claims in unfair competition's cases, proceedings before courts are the only option envisaged. ${ }^{31}$ Hence, owing to such complicated and complex legal frameworks, the very role should be allocated to courts reviewing decisions adopted by the President of UOKiK, although judicial review in Poland in the field of competition law has not been assessed overly positively in recent literature (Bernatt, 2017). As regards behaviours consisting of market access foreclosure, they may be theoretically or practically pondered by courts on the basis of the ACCP and the Act on combating unfair competition (Mioduszewski, Sieradzka, Sroczyński, 2016), which would depend on the interest of the party seeking legal protection. Then it could even amount to a 'false substitute' assuming that the case at hand might be of EU nature.

Lastly, EU harmonisation of situations covered by the Act on combating unfair competition would at once prevent misunderstandings with regard to regulations destined to rule B2C relationships, as they supposedly appeared after publishing the judgement Europamur ${ }^{32}$. Among Polish scholars (Namysłowska, 2018), a firm stance was presented opposing a purview of B2B relationships with regard to Directive 2005/29/EC 33 . Unluckily, the Polish lawmaker decided years ago to establish a separate implementing act. For that reason, the directive was implemented into the Polish legal order by the Act on combating unfair commercial practices ${ }^{34}$, overlapping the Act on combating unfair competition, which remained intact. Polish literature is replete with voices arguing against this status quo (e.g. Namysłowska, 2015). Perhaps it has to be an EU remedy to answer that issue.

31 Theoretically mediation or arbitration as well.

32 Judgement of the Court of 19.10.2017, Case C-295/16, Europamur Alimentación SA $v$ Dirección General de Comercio y Protección del Consumidor de la Comunidad Autónoma de la Región de Murcia, ECLI:EU:C:2017:782.

33 Directive 2005/29/EC of the European Parliament and of the Council of 11 May 2005 concerning unfair business-to-consumer commercial practices in the internal market and amending Council Directive 84/450/EEC, Directives 97/7/EC, 98/27/EC and 2002/65/EC of the European Parliament and of the Council and Regulation (EC) No 2006/2004 of the European Parliament and of the Council ('Unfair Commercial Practices Directive'), OJ L 149, 11.06.2005, p. 22-39.

34 Ustawa z dnia 23 sierpnia 2007 r. o przeciwdziałaniu nieuczciwym praktykom rynkowym, Dz.U. 2007 poz. 2070. 


\section{Unity and uniformity}

Since May 2004, the number of authorities and courts entitled to fully apply EU competition norms significantly increased. Hence, the challenge to guarantee that decisions and judgements adopted within the European legal sphere are not in contradiction with each other emerged so as to satisfy the objective of uniformity. Heeding that the European Commission and the Court of Justice of the European Union (hereinafter; CJEU) on the EU level, as well as national authorities and courts on the Member States' level, are assigned with competences to enforce EU antitrust law, there are several layers susceptible to potential discrepancies. In this regard, it should be borne in mind that uniformity and unity have more in common - just as the Court of Justice ${ }^{35}$ stated - the use of rules or legal concepts in national law and deriving from the legislation of a Member State may affect the unity of European Union (competition) law.

The issue of the uniform application of EU competition law was comprehensively discussed elsewhere (Dobosz, 2018). A viable non-uniformity may appear stricte during EU institutions adjudication process. ${ }^{36}$ Another avenue to unacceptable non-uniformity regards the case-law of Member States when EU antitrust norms are chosen as a legal basis for the adjudication (just to mention the patchwork of decisions in the so-called most favoured nation clauses cases - see Szmigielski, 2016, 24-29 and Ezrachi, 2016). This can be distinguished in a twofold manner - as non-uniformity in judicature within one Member State's jurisdiction and non-uniformity perceived through the lens of the comparison between acts of applied law from two (and more) Member States. Likewise, some incongruence may be discerned in relation to a decision or a judgement of a Member State authority or court and a Commission decision or CJEU judgement (see Smits, Waelbroeck, 2006). Besides, it should be borne in mind that the mentioned categories of uniformity do not include cases in which Member States' authorities and courts failed to apply Article 101 or 102 TFUE, confining themselves solely to national provisions, although the criterion of inter-state trade has been, or might have been in

\footnotetext{
35 Judgement of the Court of 14.09.10, Case C-550/07 P, Akzo Nobel Chemicals Ltd and Akcros Chemicals Ltd v European Commission, ECLI:EU:C:2010:512, para. 115.

36 For instance, some objections arouse with regard to the infringements 'by object' and 'by effect' after Allianz Hungaria judgement (judgement of the Court of 14.03.2013, Case C-32/11 Allianz Hungaria, ECLI:EU:C:2013:160). See e.g. opinion of Advocate General Wahl, delivered on 27.03.2014, Case C-67/13 P Groupement des cartes bancaires, ECLI:EU:C:2014:1958, para. 50 et seq as well as Zelger, 2017.
} 
fact fulfilled (see in particular mentioned Svetlicinii, Bernatt, Botta, 2015 and Dobosz, 2018, p. 227-237).

In spite of the fact that it is not the first time when an attempt to ascertain the border between the concepts of unity and uniformity has been made (see Sauter, 2016, p. 397 et seq.), there is a common sense implying that 'unity' refers to binding law (legislation, soft law etc.) rather than the application of law, since the latter is secondary after all (except for the so-called lawmaking application of law - its characteristics, pros and cons were researched in Golecki, 2011). Espousing this stance, uniformity ought to correspond to the application (see also Skrzydło-Niżnik, 2001, p. 99) of EU competition law, whilst unity should be comprehended as a broader notion, but equally meaningful. Hence to obtain the unity of law, both the application of law and the lawmaking process are vital in order to attain a common denominator. ${ }^{37} \mathrm{As}$ regards the application of the law, unity will affect this process from a separate angle than uniformity (see also differentiated dimensions of uniformity in Dobosz, 2018, p. 25-26) - it should imply that acts of applied law will not contravene binding norms. The EU judicature takes a comparable position in respect of unity - as a term dedicated to sources of law. ${ }^{38}$

\section{Unity and effectiveness}

The principle of effectiveness (vel effet utile) comprises a pivotal constituent of EU law development since the very beginning of the so-called integration project (Półtorak, 2002, p. 42 and Biernat, 2000, p. 28). It was invoked innumerable times by the Court of Justice of the European Union whilst new challenges were being encountered or, generally, acknowledging compliance with antitrust norms or earlier case-law. Irrespective of its incumbent position in EU law in genere, the principle of effectiveness is considered a key factor in EU competition law also. Its presence is broadly represented both in the case-law $^{39}$ and EU secondary law acts (first and foremost vide proposal for Directive $\mathrm{ECN}+$ ), not to mention its elaboration by the doctrine (e.g. Lianos,

37 It can be also deducted from judgement of the Court of 28.06.2012, Case C-477/10 P European Commission v Agrofert Holding s.a., ECLI:EU:C:2012:394, para. 32.

38 Judgement of the Court of 21.02.1991, joined Cases C-143/88 and C-92/89, Zuckerfabrik Süderdithmarschen and Zuckerfabrik Soest, ECLI:EU:C:1991:65, para. 18 and opinion of Advocate General Cruz Villalón, delivered on 26.06.2012, Case C-199/11, European Union v Otis NV et al., ECLI:EU:C:2012:388, para. 49.

39 From the recent examples - judgement of the Court of 23.11.2017, Case C-547/16 Gasorba SL et. al. v Repsol Comercial de Productos Petrolíferos SA., ECLI:EU:C:2017:891, para. 29. 
2016). Avoiding exaggerations, the principle at stake seems to be a spritus movens for the majority of changes in the EU competition legal order.

It may be also argued that effectiveness should be one of the upshots stemming from the unity of the competition law system. Likewise if relevant legal act are incompatible, their application ${ }^{40}$ will be never effective in the long term. Noticing the illustration of the public procurement issue - if an undertaking punished by one national competition authority is still entitled to enter a public tender proceeding in another Member State in spite of the directive's premise (that is, Article 57(4d) Directive 2014/24/EU), the principle of effectiveness is undermined. The objectives that the legal framework was designed for, are obscure instead.

\section{Desiderata}

Aside from some of the aforementioned, loosely set forth proposals and solutions, the desiderata listed below are to be briefly discussed.

\section{Roles to cast by the CJEU}

The missing piece in answering the struggles for the unity and effectiveness of the EU competition law system may be found in the function vested in the CJEU. In the event of an incompatibility between relevant acts, the CJEU is capable to impose an interpretation that stymies such a threat. As regards minor threats to unity, the margin for desirable interpretation will be well welcome. However, in reference to rudimentary differences between the relevant acts, the CJEU would need to weigh the principle of effectiveness and the principle of legal certainty (or even the principle of legitimate expectations). Thus the boundaries for CJEU intervention are not unlimited (compare with the thorough analysis in Marcisz, 2015, p. 130-152 and Conway, 2012, p. 97-171), a realisation that implies that the proper functioning of the legislature and, in consequence, legislation is the first and main concern. Some 'corrections' made in the course of adjudication should be available solely as the ultimate resort. Anyway, this desideratum is hard to come true as the CJEU may always choose another way (with respect of public procurement law and competition law see: Sánchez-Graells, 2019, p. 17).

40 Opinion of Advocate General Geelhoed delivered on 27.04.2006, Case C-125/05, VW-Audi Forhandlerforeningen, acting on behalf of Vulcan Silkeborg A/S v Skandinavisk Motor Co. A/S, ECLI:EU:C:2006:262, para. 36. 


\section{Towards bold EU harmonisation of all competition law pillars}

Unity will be never satisfactorily attained until a divided model of competition law exists in the European Union and its Member States. There are tremendous differences ${ }^{41}$ between Member States in the area of competition law where there are no EU rules governing certain domains (for instance, unfair competition misdeeds perceived within national competition rules sensu largo) or the cross-border criterion is not satisfied (such as invoking antitrust or merger control). The latter problem has been addressed to a certain degree in a number of cases by the CJEU. ${ }^{42}$ Answering preliminary questions, the Court of Justice took a stance, despite the purely domestic nature of the cases in question (Dobosz. 2017a). I do maintain my reluctance with regard to this ad hoc approach, especially because the gist lies elsewhere. For the sake of the unity of competition law (including EU antitrust law), and the proper functioning of the single market, a single package of relevant EU regulations and directives ought to be established. As a general rule, EU law should exclusively regulate entrepreneurs' activities in the European Union by means of, widely understood, competition law. In the proposed model of EU competition law, Member States should be still competent to establish and apply their own, specific provisions, oriented at needs and problems typical for domestic markets, providing that they have been notified (and accepted) to the European Commission beforehand. A similar solution was inserted into Regulation 139/200443. To illustrate from the Polish perspective, slotting allowances/fees may become subject of such a pre-approval from the Commission (see e.g. Modzelewska de Raad, Karolczyk, 2013). Notwithstanding the categories of competences set out in the Treaties, this proposal meets requirements of the principle of subsidiarity and proportionality. Even tackling potential political hurdles, the proposed model corresponds to current legal and economic circumstances, while the 'step by step' approach will not be that efficient any more.

Upon the condition that the EU competition law system covers all competition legal spheres (including the remaining three dimensions), heeding internal compatibility therein, the single market can materialise in its entirety.

41 Sticking to the Polish perspective, from time to time Polish authors point out the differences between the EU and domestic solutions in competition law - see e.g. Lenart, Kaczyńska, 2016, p. 37-41, Marek, 2016, p. 10 et seq., Dudzik, 2015, passim and Sikora, 2016.

42 As regards merger control see also a speech by Commission Vice-President Almunia, Weaving Europe's single competition area, European Competition Day, Rome, 10.10.2014, SPEECH/14/678, p. 5.

43 Council Regulation (EC) No 139/2004 of 20 January 2004 on the control of concentrations between undertakings, OJ L 24, 29.01.2004, p. 1. 
While effectiveness is at stake, reinforcing NCAs under the proposal for Directive ECN+ may not be conducive to address all concerns raised around the competition law system. Resources, independence, prioritisation, as aspects worth improving via that legislative initiative, are regarded as modest and insufficient (Wils, 2017a, p. 80), much less when it comes to other legal acts such as those pertaining to unfair competition proceedings where disputes are between private parties without the involvement of the authorities. Therefore, on the basis of the observations of the intricacies of competition rules across the EU and its members, reaching unity is the lesson to be learned that must involve a broader harmonisation of EU competition law far beyond the narrow scope of antitrust (and merger control). Otherwise reprehensible business conducts may elude rigorous antitrust norms, leaving harmed entrepreneurs devoid of certain, precise and effective legal tools as should be guaranteed in a borderless Europe. Public interest will not be safeguarded then either. Likewise, coordinated legislative initiatives regarding incongruence such as the one between competition and procurement law are required for the sake of certainty of law and proper exclusions of undertakings accordingly to competition rules (EU or domestic) which they have violated.

Hence a provocative question - whether the range of various and incongruent legal solutions across the European Union within broadly understood competition law all the way meets the requirements of effective legal protection? Taking into account that the Court of Justice - as aforementioned - passed a series of judgements in response to preliminary questions in highly contentious cases (see more Dobosz, 2018, p. 77-78) where the meta-norm, namely the effect on inter-state trade criterion, was not fulfilled, it should be also possible to infer the competence of Court of Justice to assess that the non-EU part of the competition law system (namely the pertinent paradigms of competition law discussed in the paper) may be embraced by EU jurisdiction in terms of (a lack of) effective legal protection ${ }^{44}$. Let's interpret the principle of effective legal protection through the lens of the single market goal. All the flaws resulting from the discrepancies between Member States in the field of competition law may generate serious obstacles for entrepreneurs. That conclusion stands in opposition to the single market idea.

As it was stated, in purely domestic cases, the Court was bold enough to smoothly find and determine the EU law regime extensively, in spite of the lack of EU jurisdiction because the EU adjudicative powers are impactful and flexible at once. Therefore, although the principle of effective legal protection applies to EU law (see more Półtorak, 2015), due to the CJEU's limited access to cases and hence issues, it is the academia which should put

44 As a partial emanation of the principle of effectiveness. 
forward ideas extending beyond the status quo, even if the problematic realms concern national legal acts in lieu of the EU ones. Not to mention the EU acts which are incompatible with each other, such as competition and procurement law. ${ }^{45}$ On this stage of EU law development, the EU competition legal system ought to capture the whole competition environment ${ }^{46}$ and duly arrange it. A mere establishment of procedural norms for some cases ${ }^{47}$ cannot be deemed effective while substantive norms differ, some of them even considerably.

\section{Presumption - interpretation in line with EU competition law}

An alternative, but of uncertain outcome, would be a presumption that any competition rules are interpreted through the prism of EU antitrust law. ${ }^{48}$ That presumption would prompt interpreting competition law sensu stricto, sensu largo and sensu largissimo in line with EU competition rules. As regards national rules enforced in parallel with the EU ones, such an approach is in general already accepted, but as shown above it is not sufficient. In case of doubts on how a specific issue should be interpreted, the approach to introduce consistency with EU competition law ought to prevail. Building up the relationship in this way would categorically promote internal compatibility, and in consequence unity, since a common denominator would be known by all interested parties. However, a properly prepared network of administrative and judicial authorities competent to deal with a wide range of legal issues, so as to guarantee a realisation of the idea, is required anyway (compare: S. Kirchner, 2005).

Although presumptions may be utilized to increase effectiveness (Ritter, 2017), they cannot be employed freely. As a matter of fact, such presumptions are well placed when, both, sound counterarguments cannot be offered and a counterfactual assessment demonstrates that much more uncertainty emerges in absence of the presumption devised. On the other hand, presumptions do not fill the gaps in law, nor put relevant legal acts in order. Furthermore,

45 Nonetheless the CJEU may activate in this sphere - see the newest opinion of Advocate General C. Sánchez-Bordon, delivered on 16.05.2018, Case C-124/17, Vossloh Laeis GmbH v Stadtwerke München GmbH, ECLI:EU:C:2018:316.

46 The newest proposal of the European Commission, which came up recently concerning a Directive of the European Parliament and of the Council on unfair trading practices in business-to-business relationships in the food supply chain, $\operatorname{COM}(2018) 173$, is a good example in this regard.

47 I.e. Regulation (EC) No 864/2007 of the European Parliament and of the Council of 11 July 2007 on the law applicable to non-contractual obligations (Rome II), OJ L 199, 31.07.2007, p. 40-49.

48 What in fact I suggested when competition and procurement law interrelate - Dobosz, 2017. 
inappropriate use of presumptions may bring effects more adverse than planned, as they concern the application of the law, which may be subject to potential non-uniformity (as explained above). Therefore, unity may take advantage of presumptions only to a limited extent.

\section{Conclusions}

The notion of competition law as such cannot be defined straightforwardly. Thus, four paradigms of competition law, either EU or national one, were differentiated. The interrelations between them deserved a separate study as cumulatively perceived competition law of the European Union and Member States appeared to be in disorder. As demonstrated, NCAs can go for an incorrect legal basis, choosing the most convenient one, as EU law does not encompass all competition related scenarios. Member States can establish legislative initiatives that raise doubts with respect of EU competition law and policy. Even juxtaposing EU and national antitrust rules with (EU) public procurement law, it is clear that they are far from compatibility, or better unity. Antitrust law similarly interrelates to IP law, consumer law etc. This remark is striking, taking into account that - for instance - regulating anticompetitive non-controlling minority shareholdings, domestic laws could work in favour of the whole EU. The Polish legal order served instead as an example demonstrating national jurisdiction that features a wide range of legal acts comprising an intricate competition law system.

To address all the concerns, the concept of unity was put forward. The scope of unity goes beyond such terms as 'compatibility' and cannot be easily conceived as an antonym of 'pluralism'. Unity involves a top-down design in the lawmaking process, in order to pursue intended goals as well as handling diverse aspects (which as such are not negative - compare Mulder, 2018). Its place in the European Union legal system can be indisputably justified through the lens of the single market - what is more, this approach is necessary to realise the internal market successfully (compare Ottanelli, 2016, p. 53). It has to be additionally stressed that striving for the internal market has recently gained much more significance and may not be as limited as before. Although in literature (Prost, 2012, p. 32-38) attention was paid to unification and universality alike, to attain a broad picture, the concept of unity was also enhanced by adjacent concepts of uniformity and effectiveness. ${ }^{49}$ Hence related observations focused on the application of law.

49 Regardless of the impossibility to draw clear borders between those terms - see also judgement of the Court of 4 October 2011, Football Association Premier League Ltd, NetMed 
Finally, in order to solve - at least partly - the articulated problems, the paper proposes a desiderata. The first one pertains to the role the CJEU can play. Once a case of direct or indirect competition nature appears before the CJEU, EU courts should consider whether the provisions at stake could be interpreted so as to accomplish unity. A great drawback is that EU courts cannot choose which issues they can deal with on their own. Another solution regards a further EU harmonisation of all competition law pillars. The current status quo is not adequate to reach unity. Unfortunately, the Effectiveness Directive will not be sufficient in this respect either. An interpretation in line with EU competition via the established presumption constitutes the third desideratum. Every time national competition rules sensu stricto, national competition rules sensu largo or competition rules sensu largissimo are about to be applied, a competent authority has to ensure that relevant provisions and terms are not contrary to EU antitrust law and policy, not to mention its goals (compare Gal, 2017). Hence this idea relies on the supremacy of EU competition law.

\section{Literature}

Almăşan, A. and Whelan, P. (Eds.). (2017). The Consistent Application of EU Competition Law: Substantive and Procedural Challenges, Berlin, Germany: Springer International Publishing.

Avbelj, M. (2006). The EU and the Many Faces of Legal Pluralism Toward a Coherent or Uniform Legal Order? Croatian Yearbook of European Law and Policy, 2, p. 377-391.

Bernatt, M. (2017). Effectiveness of Judicial Review in the Polish Competition Law System and the Place for Judicial Deference. Yearbook of Antitrust and Regulatory Studies, 9(14), p. $97-124$.

Bernatt, M. (2014). Prawo konkurencji czy prawo ochrony konkurencji? internetowy Kwartalnik Antymonopolowy i Regulacyjny, 9(3), p. 6-7.

Biernat, S. (2000). Zasada efektywności prawa wspólnotowego w orzecznictwie Europejskiego Trybunału Sprawiedliwości. In: S. Biernat (Ed.), Studia z prawa Unii Europejskiej, Kraków: Wydawnictwo Uniwersytetu Jagiellońskiego.

Casanovas, A. (2001). Unity and Pluralism in Public International Law, the Hague-New York-London: Martinus Nijhoff Publishers.

Cengiz, F. (2010). Multi-level Governance in Competition Policy: The European Competition Network. European Law Review, 35.

Conway, G. (2012). The Limits of Legal Reasoning and the European Court of Justice, Cambridge University Press.

Hellas SA, Multichoice Hellas SA et al. v QC Leisure et al. and Karen Murphy v Media Protection Services Ltd, para. 188. 
Cseres, K. (2005). Competition Law and Consumer Protection, the Netherlands, the Hague: Kluwer Law International.

Cseres, K. (2017). Rule of Law Values in the Decentralized Public Enforcement of EU Competition Law. In Jakab, A., Kochenov. D. (Eds.), The Enforcement of EU Law and Values: ensuring Member States' compliance. Oxford: Oxford University Press.

Dobosz, K. (2018). Jednolitość stosowania prawa konkurencji Unii Europejskiej przez organy i sqdy Państw Cztonkowskich, Poland, Warszawa: Wolters Kluwer.

Dobosz, K. (2018a). Od Walt Wilhelm do PZU? Czyli o zasadzie ne bis in idem oraz relacji krajowego i unijnego prawa konkurencji w dobie obowiązywania rozporządzenia nr 1/2003. Europejski Przegląd Sądowy, 9.

Dobosz, K. (2018b). (Nie)zamienne stosowanie krajowego i unijnego prawa konkurencji - o relacji między krajowym i unijnym reżimem antymonopolowym. Glosa do wyroku Sądu UE z 30 września 2016 r. w sprawie T-70/15 Trajektna luka Split d.d. przeciwko Komisji. internetowy Kwartalnik Antymonopolowy i Regulacyjny, 2, 107-119.

Dobosz, K. (2017). Trudna relacja między prawem zamówień publicznych a prawem antymonopolowym na przykładzie art. 57 ust. 4 lit. d dyrektywy 2014/24/UE. Przeglad Prawa Publicznego, 12, 72-86.

Dobosz, K. (2017a). W stronę unifikacji systemów prawa konkurencji Unii Europejskiej i państw członkowskich - uwagi na tle orzecznictwa Trybunału Sprawiedliwości Unii Europejskiej w zakresie spraw o charakterze czysto krajowym. Europejski Przeglad Saqdowy, 10, 34-38.

Dobosz, K., Scheibe, M. (2017). Pierwsze uwagi i wątpliwości po przedstawieniu projektu antymonopolowej dyrektywy efektywnościowej. Przeglad Prawa Publicznego, 6, 99-110.

Dudzik, S. (2015). Kontrola koncentracji w świetle ostatnich zmian ustawowych. internetowy Kwartalnik Antymonopolowy i Regulacyjny, 2(4), 27-41.

Dudzik, S. (2013). Procesowe nadużycie prawa jako przesłanka naruszenia art. 102 TFUE. Europejski Przeglad Sądowy, 1.

Dzierżanowski, W. (2012). Ochrona konkurencji w prawie zamówień publicznych, Warszawa: Wolters Kluwer.

Ezrachi, A. (2017). Sponge. Journal of Antitrust Enforcement, 5 (1).

Ezrachi, A. (2015). The competitive effects of parity clauses on online commerce. European Competition Journal, 2-3.

Gal, M.S. (2017). The Social Contract at the Basis of Competition Law: Should we Recalibrate Competition Law to Limit Inequality? In: I. Lianos, D. Geradin (Eds.), Competition Policy: between Equity and Efficiency, Cambridge: Cambridge University Press.

Gassler, M. (2018). Non-Controlling Minority Shareholdings and EU Merger Control. World Competition, 1.

Golecki, M. (2011). Między pewnościa a efektywnościa. Marginalizm instytucjonalny wobec prawotwórczego stosowania prawa, Warszawa: Wolters Kluwer.

Handig, Ch. (2006). Harmonisierung des Lauterkeitsrechts in der EU, Vienna.

Hou, L. (2015), Reshaping market, competition and regulation in EU utility liberalization: A perspective from telecom. Common Market Law Review, 4.

Hüschelrath, K., Schweitzer, H. (Eds.). (2014). Public and Private Enforcement of Competition Law in Europe: Legal and Economic Perspectives, Berlin-Heidelberg, Germany: Springer. 
Jurkowska-Gomułka, A. (2013). Publiczne i prywatne egzekwowanie zakazów praktyk ograniczajacych konkurencje, Warszawa: Wydawnictwo Naukowe Wydziału Zarządzania Uniwersytetu Warszawskiego.

Kępiński, M. (Ed.). (2014). System Prawa Prywatnego. Tom 15. Prawo konkurencji, Warszawa: C.H. Beck.

Kirchner, S. (2005). Conference Report - Legal Unity Through Specialized Courts on a European Level? German Law Journal, 1.

Komninos, A.P. (2008), EC Private Antitrust Enforcement: Decentralised Application of EC Competition Law by National Courts, Oxford-Portland, UK: Hart Publishing.

Komninos, A.P. (2014). The Relationship between Public and Private Enforcement: quod Dei Deo, quod Caesaris Caesari. In. P. Lowe, M. Marquis (Eds.), European Competition Law Annual 2011: Integrating Public and Private Enforcement, Implications for Courts and Agencies, Oxford and Portland, UK: Hart Publishing, 141-158.

Koutrakos, P. and Snell, J. (Eds.). (2017). Research Handbook on the Law of the EU's Internal Market, Cheltenham, UK: Edward Elgar.

Lenart, J. and Kaczyńska, T. (2016). Kiedy utworzenie nowej spółki nie będzie kwalifikowane jako utworzenie nowego przedsiębiorcy (joint venture)? Praktyczne rozważania dotyczące problematyki joint venture w polskim prawie konkurencji. internetowy Kwartalnik Antymonopolowy i Regulacyjny, 1(5), 36-51.

Lianos, I. (2016). The Principle of Effectiveness, Competition Law Remedies and the Limits of Adjudication. In: P. Lowe, M. Marquis, G. Monti (Eds.), European Competition Law Annual 2014, Oxford-Portland: Hart Publishing, 105-138.

Lianos, I., Regibeau, P. (2017). 'Vexatious'/'Sham' Litigation in EU and US Antitrust Law: A Mechanism Design Approach. Antitrust Bulletin, 4.

Malinauskaite, J. (2016). Public EU competition law enforcement in small 'newer' Member States: addressing the challenges. Competition Law Review, 12(1).

Marcisz, P. (2015). Koncepcja tworzenia prawa przez Trybunat Sprawiedliwości Unii Europejskiej, Warszawa: Wolters Kluwer.

Marek, M. (2016). Wyłączenie dystrybucji selektywnej spod zakazu porozumień ograniczających konkurencję Wyłączenie dystrybucji selektywnej spod zakazu porozumień ograniczających konkurencję. internetowy Kwartalnik Antymonopolowy i Regulacyjny, 7(5), 8-27.

Massolo, A. (2018). Bundeskartellamt vs Facebook: Time to Refresh 'GDPR's Wall'? Rivista Italiana di Antitrust, 1.

Materna, G. (2018). Projekt dyrektywy ECN+ (omówienie w aspekcie potrzeby kolejnej nowelizacji polskiego prawa ochrony konkurencji). internetowy Kwartalnik Antymonopolowy i Regulacyjny, 2, 31-49.

Miąsik, D. (2012). Stosunek stosowania prawa konkurencji do prawa wtasności intelektualnej, Warszawa: Wolters Kluwer.

Mioduszewski, M., Sroczyński, J. (2016). Art. 15. In: M. Sieradzka, M. Zdyb (Eds.), Ustawa o zwalczaniu nieuczciwej konkurencji. Komentarz, LEX.

Modzelewska de Raad, M., Karolczyk, P. (2013), „Opłaty półkowe” - między reżimem prywatno- i publicznoprawnym - polemika systemowa. internetowy Kwartalnik Antymonopolowy i Regulacyjny, 2.

Mulder, J. (2018). Unity and Diversity in the European Union's Internal Market Case Law: Towards Unity in 'Good Governance'? Utrecht Journal of International and European Law, 1 . 
Namysłowska, M. (2018). Glosa do wyroku TS z dnia 19 października 2017 r., C-295/16. Europejski Przeglad Sądowy, 4, 33-38.

Namysłowska, M. (2015). O konieczności uchylenia ustawy z dnia 16 kwietnia 1993 r. o zwalczaniu nieuczciwej konkurencji. In: D. Kasprzycki, J. Ożegalska-Trybalska (Eds.), Aktualne wyzwania prawa wtasności intelektualnej i prawa konkurencji. Księga pamiatkowa dedykowana Profesorowi Michałowi du Vallowi, Warszawa: Wolters Kluwer, 382-400.

Ottanelli, M. (2016). Cooperation between National Competition Authorities and National Regulatory Authorities - Issues of Network Interaction at the EU Level. Competition Law Review, 12(1), 53-72.

Półtorak, N. (2015). European Union rights in national courts, Alphen aan den Rijn: Kluwer Law International.

Półtorak, N. (2002). Odpowiedzialność odszkodowawcza państwa w prawie Wspólnot Europejskich, Kraków: Zakamycze.

Priess, H.-J. (2014). The rules on exclusion and self-cleaning under the 2014 Public Procurement Directive. Public Procurement Law Review, 3.

Prost, M. (2012). The Concept of Unity in Public International Law, Oxford-Portland: Hart Publishing.

Raju, K.D. (2015), The Intellectual Property Rights \& Competition Law: A Comparative Analysis, Calcutta.

Ritter, C. (2017). Presumptions in EU competition law. Available at SSRN: https://ssrn. com/abstract $=2999638$ or http://dx.doi.org/10.2139/ssrn.2999638.

Sánchez-Graells, A. (forthcoming 2019). Competition Law and Public Procurement. In: J. Galloway (ed), Intersections of Antitrust: Policy and Regulations, Oxford: Oxford University Press. Available at SSRN: https://papers.ssrn.com/sol3/papers.cfm?abstract_ $\mathrm{id}=2643763$.

Sánchez Graells, A. (2011). Public Procurement and the EU Competition Rules, Oxford and Portland, UK: Hart Publishing.

Sauter, W. (2016). Coherence in EU Competition Law, Oxford: Oxford University Press.

Sikora, K. (2016), Sporne problemy dotyczące decyzji zobowiązujących w unijnym i polskim prawie konkurencji, Europejski Przeglad Sadowy, 4, 20-27.

Sinclair, A. (2017). Proposal for a Directive to Empower National Competition Authorities to be More Effective Enforcers (ECN+), Journal of European Competition Law \& Practice, 10.

Skrzydło-Niżnik, I., Dobosz, P. (Eds.). (2001). Jedność systemu prawa a jednolitość orzecznictwa sądowo-administracyjnego $i$ administracyjnego w sprawach samorzadowych, Kraków, Poland: Zakamycze.

Skrzydło-Niżnik, I., (2001), Normy strukturalno-organizacyjne a jednolitość orzecznictwa administracyjnego $w$ sprawach samorzadowych. In: Jedność systemu prawa a jednolitość orzecznictwa sadowo-administracyjnego $i$ administracyjnego $w$ sprawach samorzadowych, Kraków, Poland: Zakamycze.

Smits, C., Waelbroeck, D. (2006). Le droit de concurrence et les droits fondamentaux. In: M. Candela Soriano (Ed.) Les droits de l'homme dans les politiques de l'Union euraopéenne, Brussels, Belgium: Larcier, 135-162.

Stolarski, K. (2018). Bank account infrastructure as an indispensable means to provide financial services - the essential facilities doctrine revisited. European Competition Law Review, 3, 124-127. 
Stolarski, K. (2015). Zakaz nadużywania pozycji dominujacej na rynkach telekomunikacyjnych w prawie Unii Europejskiej, Warszawa: Wydawnictwo Naukowe Wydziału Zarządzania Uniwersytetu Warszawskiego.

Botta, M., Svetlicinii, A., Bernatt, M. (2015). The assessment of the effect on trade by the national competition authorities of the „new” Member States: Another legal partition of the Internal Market? Common Market Law Review, 52(5), 1247-1276.

Szmigielski, A. (2016). Stosowanie klauzul największego uprzywilejowania w działalności handlowej platform internetowych w świetle prawa konkurencji Unii Europejskiej. Europejski Przeglad Sadowy, 3, 24-29.

Tosza, K. (2009). Efficiencies in Art. 82 EU: An illusionary defence? Concurrences, 35.

Weatherill, S. (2017). The Internal Market as a Legal Concept. Oxford: Oxford University Press.

Wils, W. (2017). Private Enforcement of EU Antitrust Law and its Relationship with Public Enforcement: Past, Present and Future. World Competition, 1, 3-45.

Wils, W. (2017a). The European Commission's "ECN+": Proposal for a Directive to empower the competition authorities of the Member States to be more effective enforcers. Concurrences, 4, 60-80.

Wiktorowska, A., Gajewski, S., Jakubowski, A. (2014). Zasada stabilności orzecznictwa sądów administracyjnych wobec zjawiska linii orzeczniczych. In J. Sługocki (Ed.), Dziesięć lat polskich doświadczeń w Unii Europejskiej. Problemy prawnoadministracyjne. Tom II, Wrocław, Poland: Wolters Kluwer.

Zelger, B. (2017). "By object" restrictions pursuant to Article 101(1) TFEU: a clear matter or a mess, and a critical analysis of the court's judgement in Expedia? European Competition Journal 2-3. 